\title{
Earnings Surprise, Portfolio Inertia and Stock Price Volatility
}

\author{
Shunwu HUANG \\ School of Economics, Hefei University of Technology, Hefei 230601, China \\ E-mail: bchsw2012@163.com \\ Wang CHANG \\ School of Economics, Hefei University of Technology, Hefei 230601, China \\ E-mail: changwang126126@126.com \\ Lan ZHENG \\ School of Economics, Hefei University of Technology, Hefei 230601, China \\ E-mail: lzheng28@gmail.com
}

\begin{abstract}
From the perspective of the mediation effect, this paper investigates whether institutional investors adjust their portfolios according to the listed companies earnings surprise. We find that the portfolio adjustments by institutional investors exert the mediation effect on the relationship between earnings surprise and stock price volatility. Institutional investors actively manage their portfolios in the rising market, which induces the stock price volatility; while they less adjust their portfolio in the falling market, the volatility declines. This paper helps understand the role of institutional investors in the fluctuation of stock prices, and provides a new basis for decision making of regulatory administration.
\end{abstract}

Keywords institutional investor; earnings surprise; mediating effect; portfolio inertia; stock price volatility

\section{Introduction}

Stock price volatility is one of the central issues of concern in academia and industry. Particularly, there are ups and downs of the "roller-coaster" prices in the Chinese A-share stock market, and its magnitudes of volatility are huge enough to rarely present in the world. Although the striking fluctuations on share prices provide some opportunities for investors, they are more accompanied by risks that make investors suffer heavy losses on a general basis, which seriously constrains the healthy development of Chinese capital market. In literature, a number of studies have addressed the sources of price volatility and ways to reduce volatility, however, no unanimous conclusion is reached. Clearly, it is important to examine this issue in-depth from new perspectives.

Under the strategic guidance of the CSRC (China Securities Regulatory Commission) to develop institutional investors in a super-normal scale, institutional investors have been developing at a fast-rising rate in China's securities market. It becomes more common for institutional

Received September 23, 2014, accepted February 15, 2015

Supported by National Social Science Foundation of China (14BJY181) 
investors represented by fund companies to dominate the top 10 major shareholders of listed companies, which leads to the structural change in the Chinese capital market investment, that is, the shift from individual investors to institutional investors. By the end of 2012, there are 57,135 institutional investor accounts that own 12 trillion Yuan of the A-share capitalization, which accounts for $66 \%$ of market values in A-share circulation. Generally, institutional investors manage their investment assets by means of portfolios. According to the provisions of Interim Measures for the Administration of Securities Investment Funds (1997), concerning fund portfolio, the number of shares that a fund can hold must not exceed $10 \%$ of the fund net asset value. Therefore, in theory, institutional investors portfolio adjustments may have a significant impact on related individual stock prices.

In order to achieve optimal portfolios and maximum profits, institutional investors make efforts to search all the public and private information, and decide whether to adjust portfolios ${ }^{[1]}$. As one of the most important accounting information, earnings surprise is the deviation from investors' expectations of actual earnings of the company, and its size depends on not only the relevance of past financial information and the future earnings, but also the accuracy of investors' expectations. When a company releases an earnings announcement, earnings surprise may arise because previously uncertain information becomes certain, which, in turn, generates new uncertainties. Essentially, earnings surprise is ever-changing new information, which reveals the uncertainty of the information. Compared to the individual investors, institutional investors are usually considered as "sophisticated investors". They appear to have advantage of gathering, processing, and utilizing information with a stronger investment sense and more specialized investment vehicles. Taking profits and risks into account, institutional investors adjust their portfolios, which is the result to hedge the uncertain information.

It is reasonable to examine the impacts of investors' portfolio adjustments on the relationship between earnings surprise and stock price volatility from the perspective of the mediation effect . As shown in Figure 1, earnings surprise in itself does not directly impact the share prices; while, in the form of a message into the market, it indirectly leads to share price volatility by means of investors. In other words, the investors' trading is indispensable intermediary step between earnings surprise and stock price volatility, for which their trading characteristics (activeness or inertia) is essential. In Figure 1, the investors' trading is an intermediary variable, and its magnitudes determine the effects of earnings surprise on stock price volatility. With regard to earnings surprise of listed companies, institutional investors take actions on decisions of whether and how to adjust their portfolios, which in turn, leads to the possible impact on the share prices. In view of the dominance of institutional investors in China's capital market during the sample period, this paper focuses on the portfolio adjustments by institutional investors as an intermediary variable to expand research.

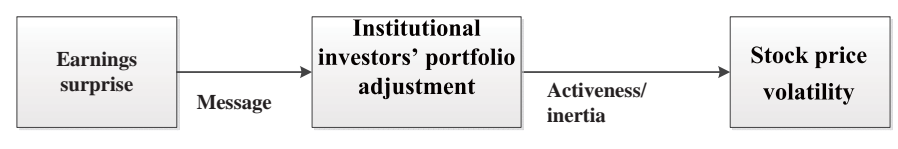

Figure 1 Relationship between earnings surprise, portfolio adjustment and stock price volatility 
Based on regular announcements data from A-share listed companies over the period 2007 to 2012, this study investigates whether earnings surprise of listed companies contributes to institutional investors' portfolio adjustments from the perspective of mediation effects, which in turn, results in the stock price volatility. The research indicates the existence of corresponding mediation effect: In the face of earnings surprise, institutions investors actively adjust their portfolios in the rising market to amplify the share price volatility; while in the falling market, institutional investors barely adjust their portfolio positions, and to some extent, exhibit portfolio adjustment inertia, which in turn, reduce the stock price volatility.

The contributions of this paper are fourfold. First, we propose the concept of "portfolio adjustment inertia" for the first time. Second, this study focuses on individual stocks rather than the market (index) level, which is more in line with institutional investors dominance in the capital market during the sample period. Third, this paper examines the relationship between earnings surprise, institutional investors and stock price volatility from the perspective of mediation effects, which has important implications for in-depth understanding of stock price fluctuations in Chinese capital market, as well as of the investment characteristics of institutional investors. Fourth, this study finds the different effects that institutional investors manage their portfolio adjustments on stock price volatility in the rising and falling stock markets, which is quite different from previous literature of single conclusion ("aggravation" or "stability" theory). Therefore, this paper is a essential complement to the existing literature.

The structure of this paper is organized as follows. Section 2 reviews the literature on the connection among information uncertainty, institutional investor and stock price volatility. Section 3 presents four main hypotheses, describes data selection criteria, and provides definition of the variables. In Section 4, we present descriptive statistics of variables, introduce the construction of the models, and also report regression results. Section 5 provides a summary of our findings and some concluding remarks.

\section{Literature Review}

We review the existing literature from the connection among information uncertainty, institutional investor and stock price volatility.

The first is the relationship between information uncertainty and stock price volatility. There is evidence that information for the fluctuation of asset prices is asymmetric. [2] investigated the conditional covariance of stock returns using EGARCH model for the period July 1926-December 1990, and found the response of volatility to bad news is strong while to good news is weak. [3] constructed a model to show that investors react more seriously to bad news than to good news and also dislike assets for which information is uncertain. These effects induce ambiguity premia that depend on idiosyncratic risk. This conclusion is supported by [4]. He finds, as the uncertainty is increasing, investors place greater weight on bad earnings news.

Scholars study the effects of ambiguous information on stock price volatility from the perspective of earning announcement. Using European exchange listed firms from 1997 to 2010, [5] found that information uncertainty played an important role in earning announcement drift: information uncertainty is positively related to future abnormal return and abnormal 
trading volume. Based on Chinese listed firms, [6] discussed the existence and persistence of Post-Earnings-Announcement Drift (PEAD), and found that information quality affect PEAD through two ways: The indirect way is that, since most stocks with poor information quality are in the high earnings surprise group, information quality affect PEAD through earnings surprise; the direct way is that portfolio with poor information quality has a high abnormal return after earning announcement. [7] used random walk model to calculate earnings surprise and found that investors information demand prior to earnings announcements has no effect on the relationship of contemporary abnormal return and earning surprise, but the demand in the following earnings announcements has negative effect. [8] constructed a model to study the effects of risk and ambiguity on optimal portfolios and equilibrium asset prices, and showed that the desire of investors to hedge ambiguity leads to portfolio inertia and excess volatility. [8] did a valuable theoretical work, but the work just views portfolio inertia and asset price as a result of ambiguous information. We further discuss the role of portfolio adjustment in the stock price volatility and support it with empirical evidence.

The second is the relationship between institutional investor and market volatility. Do institutional investors lessen or strengthen the market volatility? The answer is not clear, though more research support the former. Using data from American stock market between January 1, 1988 and December 31, 1996, [9] came to conclusions that abnormal return and abnormal turnover are both positively related to the percentage of institutional ownership. These results are consistent with positive feedback herding behavior of some institutions. Therefore, the institutions play a more important role in market volatility. [10] found that the trading of better informed short-term institutional investors forecasts future stock returns and is also positively related to future earnings surprises, while long-term institutions trading did not. So, the shortterm trading of institutions may intensify the stock price volatility. [11] conducted a simple theoretical model to analyze the impact of institutional herding on asset prices and showed that the herding positively predicts short-term returns, but negatively predicts long-term returns. [1] concluded that institutional owners decrease their positions prior to earnings announcements in order to avoid losses, and increase their positions of which underreact to the earnings announcements in the post-announcement period. The changes in institutional positions make a difference to the abnormal return before and after the earnings announcements. Based on high-frequency data, [12] proved that the volatility of the institutional stockholding ratio is the main source of index volatility and had significant effect on general corporate investors and important individual investors. $[13,14]$ shared the same points that institutional investor do not stabilize the market, but facilitate the market volatility.

Minority researchers sustained that institutional investors stabilize the market. [15] investigated the differences in the holdings of institutional investors and individual investors between March and November 2000. They found institutional investors held stocks with less return volatility than individual investors and performed better. According to this view, institutional investors lower the market volatility. Based on Shanghai stock market from 2001 to 2004, [16] used non-parametric test and found there is a significant negative relationship between institutional investor holdings and stock volatilities after controlling the firm size. This conclusion is questionable, as the size and number of Chinese institutional investors are not big enough to 
make an impact on the whole market in that period.

The third is the existence and cause of portfolio inertia. Whether investors' portfolio adjustment is inert or not, the answer is not clear. Based on research into personal pension account, [17] found that household trading was highly inactivity and showed a certain degree of portfolio inertia. [18] used transaction data from representative sample of US individuals and families to document the extent of household portfolio inertia which contribute to stock market instability. However, [19] investigated the 66,465 households of accounts at a large discount broker during 1991 to 1996 and showed no evidence of portfolio inertia, but due to overconfidence, household turned over 75 percent of its portfolio annually and result in a poor performance. Through introducing the concept of ambiguity, [20] found the evidence of institutional investor portfolio inertia under the assumptions of Choquet expected utility.

For the cause of portfolio inertia, [21] found that transaction cost and information one are important for investors to implement a consistently profitable accruals strategy. If the costs are too high, investors can profit from adjusting the portfolio. So transaction cost is the main source of portfolio inertia, but it maybe just make sense for the individual investors. [22] studied the portfolio choice problem under ambiguity, and proved that portfolio inertia is defined when there is belief commonality between the optimists and pessimists of the market. Therefore, the common belief is the main source of portfolio inertia. [23] analyzed investors' portfolio selection problems in a two-period dynamic model of Knightian uncertainty. Incorporating investors updating behavior, they accounted for the existence of portfolio inertia in this twoperiod framework: New observation in the first period will lead portfolio inertia in the second period if the degree of Knightian uncertainty is sufficiently large. So, uncertainty is another source of portfolio inertia.

In conclusion, the existing literatures ignore to study the way of uncertain information affecting stock price. From the perspective of the mediation effect, we will first define the logical relationship of uncertain information, portfolio adjustment and price volatility, and then explore how earnings surprise affect price volatility by means of portfolio adjustment of institutional investor.

\section{Methodology}

\subsection{Hypothesis}

Earnings surprise depend largely on the accuracy of the investors' expectation on the company's future earnings. The higher the degree of information ambiguity, the less is the accuracy of earnings expectation, and the greater is the earnings surprise ${ }^{[6,24]}$. In a mature market, this accuracy mainly comes from two ways: The first is the relevance of the company's future earnings and its past public financial information; the second is investors' forecast ability on the company's future earnings. In A-stock market, however, the factors that influence the earnings surprise are much more complicated, and the phenomenon of incomplete information is much more serious, such as the immature market, defects of system design, inadequate disclosure of information of listed companies, and the limited ability of investors to obtain and digest information, etc. Therefore, it is common to find that the listed company's actual earnings are above or below expectations when the company releases the earnings announcement. In this 
context, we propose the following hypotheses:

H1: It is often observed the existence of earnings surprise in A-share market.

Generally, institutional investors comply with the asset portfolio theory to manage their portfolio investments. They decide whether to adjust portfolios through all the information they collect and process. There are a variety of factors influence this decision, such as earnings surprise, transaction costs, heterogeneous beliefs, emergencies, etc.

H2: After controlling for other factors, the greater the earnings surprise, the larger the magnitudes for institutional investors to adjust their portfolios.

Institutional investors have gradually dominated A-stock market, enabling them to impact share prices significantly. Assuming other factors constant, institutional investors actively adjust their portfolios will lead fluctuations on related stock prices. Specifically, largely reducing shares may produce negative abnormal returns, while largely increasing shares may produce positive abnormal returns. On the other hand, if institutional investors hold their portfolio constant or adjust slightly, that is, to present a portfolio adjustment inertia, the related stock price volatility should be relatively small.

H3: In terms of the earnings surprise of listed companies, the stronger the inertia of institutional investors to adjust their portfolios, the smaller is related stock price volatility, and vice versa.

H4: (Existence of the mediation effect): If the hypothesis 2 and 3 are well established, then institutional investors' portfolios adjustments will impose a significant mediation effect on the relationship between earnings surprise and share price volatility.

\subsection{Data}

Because of the relatively small amount and scale of institutional investors in China before 2007, we choose all A-share listed companies over the period 2007-2012 as the initial sample and then exclude some observations according to the following standards:

1) Remove the listed companies without a full fiscal year.

2) Eliminate the financial sector shares, ST'special Treatment'shares, and companies with cross-listings.

3) Remove the samples with major assets reorganization during the sample period.

4) Eliminate observations in which the percentage share of institutional quarter-end stock holdings is less than $5 \%$ of the total shares outstanding during the sample period.

5) Exclude observations in which the number of institutional investors among the quarterend top 10 unrestricted stakeholders is less than two during the sample period.

6 ) Exclude securities with less than one year of listing in order to reduce the possible IPO effect.

7) Eliminate abnormal and missing data from the sample.

8) Continuous variables are winsorized at the $1 \%$ level and $99 \%$ level in order to control the effect of extreme values.

In this paper, we consider every regular report from each listed company as an independent observation and get a total of 20143 valid observations. The report involved is between the first quarter of 2007 and the third quarter of 2012 and the data covered is for the period December 
1, 2006, through October 31, 2012. We obtain the data from Wind database and CSMAR database.

This paper defines earnings announcement day as the event day. As the disclosure time requirements for the quarterly, semi-annual and annual report are different, and the earnings announcement date for each sample also varies, we set the different event window in Table 1 to reasonably examine the change of each observation in the window period, especially to reduce the impact of data overlap.

Table 1 The determination of time period of variables

\begin{tabular}{cccc}
\hline \multirow{2}{*}{ Regular report } & $\begin{array}{c}\text { Time period of } \\
\text { earnings }\end{array}$ & $\begin{array}{c}\text { Observed Date of } \\
\text { portfolio } \\
\text { announcement }\end{array}$ & $\begin{array}{c}\text { Window period of } \\
\text { stock price }\end{array}$ \\
\hline 1st quarter report & {$[$ Apr 1, Apr 30] } & Mar 31/Jun 30 & volatility \\
Semi-annual report & {$[$ Jul 1, Aug 31] } & Jun 30/Sep 30 & {$[-21,21]$} \\
3rd quarter report & {$[$ Oct 1, Oct 31] } & Sep 30/Dec 31 & {$[-21,42]$} \\
Annual report & {$[$ Jan 1, Apr 30] } & previous year Dec 31/Jun 30 & {$[-21,21]$} \\
\hline
\end{tabular}

\subsection{Variables}

1) Earnings surprise

In this paper, we follow the method of $\mathrm{Yu}$ and Wang ${ }^{[6]}$ to measure accounting earnings $(E)$ using the rate of total return on assets. Under the normal circumstance, if company's information quality is high, there is slightly change in rate of return on assets every year. The formula of earnings surprise $(U E)$ for stock $i$ at time $\tau$ th is

$$
U E_{i, \tau}=E_{i, \tau}-E_{i, \tau-4}
$$

2) Portfolio adjustment by institutional investors

The institutional investors consist of securities investment fund, QFII, social security fund, insurance fund, company annuity, trust, financial companies, brokerage, securities financial products, etc. Because it is difficult to obtain each institutional investor's quarter-end holdings for each equity at each regular report, we use the aggregate holdings of each security owned by all institutional investors as an alternative portfolio, and the change in the proportion of institutional shareholdings within two consecutive regular reports is considered as the adjustment of its asset portfolio. If the change is significant, it is said to be portfolio adjustment activeness; otherwise, it is called portfolio adjustment inertia. Our observations are based on the Wind database of "the proportion of the unrestricted shares outstanding owned by all institutional investors. The formula for stock $i$ at th period in institutional investors' portfolio adjustment is

$$
\Delta I O_{i, \tau}=I O_{i, \tau}-I O_{i, \tau-1}
$$

3) Stock price volatility

In order to remove the effect of systemic factors on the individual stock prices, we use market adjustment model to calculate the abnormal rate of return so as to more objectively 
examine the influence of institutional portfolio adjustment on individual stock prices:

$$
\begin{aligned}
& A R_{i t}=R_{i t}-R_{m t} \\
& R_{i t}=100 *\left(p_{i, t}-p_{i, t-1}\right) / p_{i, t-1} \\
& R_{m t}=100 *\left(p_{m, t}-p_{m, t-1}\right) / p_{m, t-1}
\end{aligned}
$$

where $t$ stands for trading day, $p$ is stock price, $p_{m}$ represents the market index, $A R_{i t}, R_{i t}$ and $R_{m t}$ are the abnormal rate of return, real rate of return, and normal rate of return for stock $i$ at time $t$, respectively. The normal rate of return for main board stocks in Shanghai and Shenzhen stock market is calculated as the Shanghai composite index, while normal rate of return for small and medium-sized market, and growth enterprise market (GEM) is calculated as the small and medium-sized board index.

The average abnormal rate of return for stock $i$ at $\tau$ th period in the window period $\left(t_{1} \sim t_{2}\right)$ is

$$
\overline{A R_{i, \tau,\left[t_{1}, t_{2}\right]}}=\frac{1}{t_{2}-t_{1}} \sum_{t=t_{1}}^{t_{2}} A R_{i t}
$$

The common way to measure stock price volatility is standard deviation of stock daily rate of return during a long period (usually a quarter). The stock price volatility for stock $i$ at $\tau$ th period in the window period $\left(t_{1} \sim t_{2}\right)$ is expressed as the standard deviation $(\sigma)$ of abnormal rate of return:

$$
V O L_{i, \tau,\left[t_{1}, t_{2}\right]}=\sigma_{i, \tau,\left[t_{1}, t_{2}\right]}=\left[\frac{1}{t_{2}-t_{1}} \sum_{t=t_{1}}^{t_{2}}\left(A R_{i t}-\overline{A R_{i, \tau,\left[t_{1}, t_{2}\right]}}\right)^{2}\right]^{\frac{1}{2}}
$$

4) Control variables

With reference to the related literature, this paper selects the following control variables, which are shown in Table 2.

\section{Empirical Results and Analysis}

\subsection{Statistics Analysis}

1) Institutional shareholdings

Table 3 shows the institutional shareholdings during the sample period. It can be seen that the number of institutional shareholders in each listed company has fluctuation, but the proportion of institutional stockholdings has increased steadily. Specifically, average number of institutional shareholders in each listed company increased from 19.63 in 2007 to 31.44 in 2012, and average proportion also increased from $22.32 \%$ in 2007 to $37.65 \%$ in 2012 . This shows that Chinese stock market has experienced the transformation from individual investors dominance to institutional investors dominance, and the behavior of institutional investors have a more pronounced impact on individual stocks. 
Table 2 Definitions of variables

\begin{tabular}{|c|c|c|}
\hline $\begin{array}{l}\text { Variable } \\
\text { name }\end{array}$ & Symbol & Definition \\
\hline $\begin{array}{l}\text { stock price } \\
\text { volatility }\end{array}$ & $V O L$ & $\begin{array}{l}\text { standard deviation of abnormal rate of return during the window } \\
\text { period }\end{array}$ \\
\hline $\begin{array}{l}\text { accounting } \\
\text { earning }\end{array}$ & $E$ & rate of return on total assets at regular announcement day \\
\hline $\begin{array}{l}\text { earnings } \\
\text { surprise } 1\end{array}$ & $U E$ & $\begin{array}{l}\text { the difference of rate of return on assets between current earnings } \\
\text { and earnings from previous year }\end{array}$ \\
\hline $\begin{array}{l}\text { earnings } \\
\text { surprise } 2\end{array}$ & Due & $\begin{array}{l}\text { dummy variable, to define earnings surprise as a dummy variable } \\
\text { (seeing the section of robustness test) }\end{array}$ \\
\hline asset portfolio & IO & $\begin{array}{l}\text { proportion of the unrestricted sale shares outstanding owned by } \\
\text { institutional investors }\end{array}$ \\
\hline $\begin{array}{l}\text { portfolio } \\
\text { adjustment }\end{array}$ & $\Delta I O$ & $\begin{array}{l}\text { change in the proportion of the unrestricted sale shares out- } \\
\text { standing owned by institutional investors }\end{array}$ \\
\hline $\begin{array}{l}\text { book-to- } \\
\text { market ratio }\end{array}$ & $B M$ & $\begin{array}{l}\text { ratio of book net asset to market value on regular announcement } \\
\text { day }\end{array}$ \\
\hline $\begin{array}{l}\text { transaction } \\
\text { cost }\end{array}$ & $T R A C$ & average share price during the window period \\
\hline $\begin{array}{l}\text { profit } \\
\text { distribution }\end{array}$ & Dpro & $\begin{array}{l}\text { dummy variable, if there is large stock dividends (that is, for } \\
\text { every } 10 \text { shares, total of convertible and distributed shares reach } \\
\text { or exceed } 3 \text { shares), then the value is } 1 \text {, otherwise } 0\end{array}$ \\
\hline $\begin{array}{l}\text { investor senti- } \\
\text { ment }\end{array}$ & $T U R V$ & average abnormal turnover rate in the window period \\
\hline asset size & $S I Z E$ & $\log ($ total asset) \\
\hline $\begin{array}{l}\text { earnings pre- } \\
\text { announcement }\end{array}$ & FORC & $\begin{array}{l}\text { dummy variable: If there is earnings pre-announcement prior to } \\
\text { its official release, then the value is } 1 \text {, otherwise } 0\end{array}$ \\
\hline $\begin{array}{l}\text { lag of } \\
\text { announcement }\end{array}$ & $L A G$ & $\begin{array}{l}\text { number of days between the regular report deadline and the } \\
\text { earnings announcement day }\end{array}$ \\
\hline $\begin{array}{l}\text { industry } \\
\text { factor }\end{array}$ & $I N D U$ & $\begin{array}{l}\text { with reference to SEC (Industry Classification Guidance for } \\
\text { Listed Companies (2001)), we have a total of } 12 \text { sectors by ex- } \\
\text { cluding the financial sector, measured with } 11 \text { dummy variables }\end{array}$ \\
\hline year factor & $Y E A R$ & $\begin{array}{l}\text { a total of } 6 \text { years, to measure with five dummy variables and set } \\
\text { the year of } 2007 \text { as the base year }\end{array}$ \\
\hline
\end{tabular}


Table 3 Basic statistics of institutional shareholdings

\begin{tabular}{lccc}
\hline Year & $\begin{array}{c}\text { Average number of } \\
\text { institutional investors } \\
\text { in each listed company }\end{array}$ & $\begin{array}{c}\text { Average proportion of institutional } \\
\text { stockholdings in } \\
\text { each listed company }(\%)\end{array}$ & $\begin{array}{c}\text { Number of listed } \\
\text { companies }\end{array}$ \\
\hline 2007 & 19.63 & 22.32 & 1415 \\
2008 & 18.29 & 26.31 & 1514 \\
2009 & 26.38 & 34.74 & 1644 \\
2010 & 24.89 & 37.06 & 2006 \\
2011 & 25.97 & 38.13 & 2295 \\
2012 & 31.44 & 37.65 & 2451 \\
\hline
\end{tabular}

2) Descriptive statistics of variables and correlation tests

Table 4 shows the descriptive statistics of the variables. The mean, median value and standard deviation for all the sample of $U E$ are $-0.03 \%,-0.1 \%$ and $2.44 \%$, respectively. This suggests that earning surprise is widely existed among Chinese listed corporations, and the wider distribution. This, to some extent, supports Hypothesis 1. The standard deviation of 10.62 for $\Delta I O$ indicates that the difference of institutional investors to adjust their portfolios is very significant. The minimum level of 0.49 and maximum level of 25.92 for the total sample of $V O L$ suggest that it is notable for the difference on the individual stock price volatility in the sample period. For control variables, the mean of $E$ is 3 and its standard deviation is 3.93 , stating that the average profitability for the sample stocks is quite low, but the variation is significant. The mean value of $I O$ is 37.42 , showing that the average proportion of sample stocks owned by institutional investors is relatively high. This is consistent with the results shown in Table 3. The standard deviation of $I O$ is up to 19.93, revealing the large difference on the proportion of institutional holdings for the sample stocks. The sample stocks tend to be overvalued, which can be seen from average value of 0.33 for $B M$. The standard deviation of TRAC is 10.84, showing that there is large variation on sample stocks' trading costs. The mean level of Dpro is 0.05 , which suggests that the percentage of listed companies engaging in large stock dividends is relatively low. However, the distribution of profits is only presented in the annual or semi-annual reports, resulting in the decreased value of Dpro, which is selected from quarterly observations. The mean of 1.69 and standard deviation of 1.96 for TURV show that abnormal turnover ratio for sample stocks are relatively low, but the difference is still significant. Apparently, this does not indicate the low turnover ratio for A-share. Due to the logarithmic mode, the standard deviation of SIZE is only 0.49, leading to the smaller differences in asset size. The mean of 0.21 for FORC show that there are relatively fewer listed companies releasing earnings pre-announcements. This can be attributed to China's relevant policies and laws. More specifically, it is the listed companies with significant changes in earnings that require issuing earnings pre-announcements. Seen from the change in $L A G$, we find that the number of listed companies to issue an earnings announcement on a regular basis will increase with the passage of time. 
Table 4 Descriptive statistics of variables

\begin{tabular}{ccccccccc}
\hline Variable & Minimum & $25 \%$ & Median & Mean & $75 \%$ & Maximum & Std. Dev. & No. of Obs. \\
\hline UE $(\%)$ & -9.99 & -1.00 & -0.1 & -0.03 & 0.79 & 9.98 & 2.44 & 20143 \\
$\Delta I O(\%)$ & -49.94 & -2.67 & 0.88 & -0.08 & 3.21 & 49.66 & 10.62 & 20143 \\
VOL $(\%)$ & 0.49 & 1.79 & 2.42 & 2.35 & 2.96 & 25.92 & 0.85 & 20143 \\
UE $(\%)$ & -41.61 & 0.66 & 2.07 & 3.00 & 4.54 & 33.98 & 3.93 & 20143 \\
IO $(\%)$ & 5.00 & 20.36 & 35.84 & 37.42 & 52.27 & 95.73 & 19.93 & 20143 \\
BM & -0.94 & 0.19 & 0.29 & 0.33 & 0.43 & 2.80 & 0.21 & 20143 \\
TRAC & 1.49 & 7.26 & 10.73 & 13.50 & 16.28 & 225.15 & 10.84 & 20143 \\
Dpro & 0.00 & 0.00 & 0.00 & 0.05 & 0.00 & 1.00 & 0.23 & 20143 \\
TURV $(\%)$ & -2.53 & 0.47 & 1.33 & 1.69 & 2.62 & 17.20 & 1.96 & 20143 \\
SIZE & 5.75 & 9.12 & 9.43 & 9.47 & 9.78 & 11.65 & 0.49 & 20143 \\
FORC & 0.00 & 0.00 & 0.00 & 0.21 & 0.00 & 1.00 & 0.45 & 20143 \\
LAG & 8 & 26 & 30 & 45 & 58 & 121 & 27 & 20143 \\
\hline
\end{tabular}

In addition, the Pearson correlation coefficient test shows that three core variables ( $U E$, $\triangle I O$ and $V O L)$ are significantly positively correlated and the estimated coefficient is less than 0.5. (Due to space limits, we omit the table for the correlation coefficients). This suggests that there do not exist apparent multicollinearity among core variables.

3) Statistics of core variables classified by earnings surprise

In order to observe earnings surprise, and changes in institutional investor's portfolio adjustments as well as stock price volatility, we classify the sample according to two criteria. One is to put the positive $U E$ sample into "good group" and negative $U E$ sample into "bad group". The other is to rank $U E$ in an ascending order and then equalize them into ten parts. Among them, the closer to the two ends of the percentile, the larger is the changes in earnings surprise.

We can see from Table 5, no matter what classification used, it is common for the presence of earnings surprise, and again it supports Hypothesis 1. The M-W test results show that, due to the average value, there is no significant difference on the proportion adjustment of institutional stockholdings between good and bad information groups, but the high volatility and significant difference on the proportion adjustment are found during the window period. This suggests that, compared to the "good information group", institutional investors show little sign of reducing "bad information group". That is, for stocks with declining earnings surprise, institutional investors show the inertia of portfolio adjustment.

To further examine the classification of $S U E$ from the lowest to the highest, we can see that when $U E$ increases from -4.82 to $0.07, \Delta I O$ rises from 0.47 to the highest level of 1.89 ; and when $U E$ rises from 0.07 to even further, $\Delta I O$ falls and eventually reduces by 0.23 . From the trend of change, we find that $\Delta I O$ exhibits the feature of "inverse U-shape" curve (that is, to rise first, and then to fall). This suggests that as earnings surprise increase, institutional investors gradually purchase more stocks, but when it reaches the highest level, the increase in purchasing stocks is getting smaller and smaller with the further growth of earnings surprise, which manifests the inertia of portfolio adjustment. Again, this reflects the different trading 
features of individual investors from institutional investors, since the latter is more rational and able to inverse trade timely. Meanwhile, with the rise of $U E, V O L$ increases from the lowest group of 2.38 to the highest group of 2.63 (albeit with fluctuation). It means that stock price volatility is becoming greater with the rise of earnings surprise. Combined the variability of $U E, \triangle I O$ and $V O L$, we can tell that institutional investors prefer steady-going business; before stock prices rise to the high levels, they keep purchasing more shares to steadily push up the trading volatility; after the high levels, the increasing volatility apparently cannot be attributed to institutional investors, but mainly to the non-rational trading of individual investors. Due to the portfolio adjustments inertia, institutional investors usually do not respond fully to large earnings surprise. In contrast, because of the disposition effect, individual investors prefer to continue holding stocks when earnings surprise is negative and stock prices fall, while they prefer to sell shares to push up stock price volatility when earnings surprise is positive and stock prices rise.

Table 5 Statistics of core variables classified by earnings surprise

\begin{tabular}{cccccc}
\hline & Group & SUE & $\Delta I O$ & VOL & No. of Obs. \\
\hline Classified by & Bad information group & -1.62 & 0.86 & 2.33 & 10428 \\
positive/ & Good information group & 1.54 & 0.90 & 2.50 & 9715 \\
negative & M-W test Z-value & & -0.625 & $-14.759 * * *$ & \\
signs & $(p$-values $)$ & & $(0.532)$ & $(0.000)$ & 2014 \\
\hline Classified & 1 & -4.82 & 0.47 & 2.38 & 2014 \\
by & 2 & -1.94 & 0.22 & 2.28 & 2014 \\
size & 3 & -0.99 & 0.72 & 2.28 & 2014 \\
& 4 & -0.48 & 1.02 & 2.32 & 2014 \\
& 5 & -0.15 & 1.58 & 2.39 & 2014 \\
& 6 & 0.07 & 1.89 & 2.46 & 2014 \\
& 7 & 0.35 & 1.73 & 2.42 & 2014 \\
& 9 & 0.81 & 0.84 & 2.45 & 2014
\end{tabular}

Note: Numbers in parentheses are $t$-statistics of the regression coefficients. ${ }^{* * *}, * *$, and ${ }^{*}$ correspond to statistical significance at the $1 \%, 5 \%$, and $10 \%$ level, respectively.

\subsection{Regression Results and Analysis}

In terms of the mediation effect proposed in [25] and their test procedures, this paper constructs the following regression models to examine the relationship among earnings surprise, institutional investors' portfolio adjustment and share price volatility:

$$
\begin{aligned}
& \Delta I O_{i, \tau}=\alpha_{0}+\alpha_{1} U E_{i, \tau-1}+\Sigma \alpha_{x} Z_{i, \tau-1}^{1}+\mu_{i, \tau}^{1} \\
& V O L_{i, \tau}=\beta_{0}+\beta_{1} U E_{i, \tau-1}+\Sigma \beta_{x} Z_{i, \tau-1}^{2}+\mu_{i, \tau}^{2}
\end{aligned}
$$




$$
V O L_{i, \tau}=\gamma_{0}+\gamma_{1} \Delta I O_{i, \tau}+\gamma_{2} U E_{i, \tau-1}+\Sigma \gamma_{x} Z_{i, \tau-1}^{3}+\mu_{i, \tau}^{3}
$$

where, $Z^{1}, Z^{2}$ and $Z^{3}$ are corresponding control variables respectively, $\mu^{1}, \mu^{2}$ and $\mu^{3}$ are corresponding error measures, respectively.

1) Regression results and analysis of Model (5)

Model (5) is used to investigate whether institutional investors adjust their portfolio positions in line with earnings surprise of listed companies. Table 3 shows that there is an annual increase in the proportion of institutional shareholdings, so this paper divides the total sample into six sub-samples based on the year. Following the method of [26], we select previous values of $B M, T R A C$, Dpro, $E$ and $I O$ as control variables in Model (5). With expectation, if institutional investors adjust their portfolios according to the changes in earnings surprise, then $\alpha_{1}$ should be positive. That is, the larger the earnings surprise of listed companies, the greater is the scales of portfolio adjustment for the institutional investors. Regression results are shown in Table 6 .

Table 6 Regression results of Model (5)

\begin{tabular}{cccccccc}
\hline Variable & Total Sample & 2007 & 2008 & 2009 & 2010 & 2011 & 2012 \\
\hline$U E$ & $0.07 * *$ & $0.24 * * *$ & -0.04 & $0.18 * *$ & -0.06 & 0.05 & -0.06 \\
& $(2.35)$ & $(3.54)$ & $(-0.48)$ & $(2.32)$ & $(-0.45)$ & $(-0.63)$ & $(-1.01)$ \\
BM & $2.88 * * *$ & -2.74 & $2.28 * *$ & $5.74 * * *$ & 1.49 & $2.25 * * *$ & $0.94 *$ \\
& $(7.53)$ & $(-1.13)$ & $(2.28)$ & $(4.40)$ & $(1.42)$ & $(3.39)$ & $(1.68)$ \\
TRAC & $0.14 * * *$ & $0.24 * * *$ & $0.28 * * *$ & $0.16 * * *$ & $0.14 * * *$ & $0.13 * * *$ & $0.10 * * *$ \\
& $(17.92)$ & $(11.31)$ & $(10.16)$ & $(6.23)$ & $(7.87)$ & $(9.93)$ & $(5.93)$ \\
Dpro & $-4.00 * * *$ & $-5.28 * * *$ & $-3.38 * * *$ & $-4.03 * * *$ & $-3.28 * * *$ & $-2.53 * * *$ & 0.77 \\
& $(-12.43)$ & $(-5.64)$ & $(-3.43)$ & $(-4.52)$ & $(-4.96)$ & $(-4.76)$ & $(0.89)$ \\
$E$ & $-0.22 * * *$ & $-0.17 * *$ & -0.09 & $-0.16 * *$ & $-0.30 * * *$ & $-0.27 * * *$ & $0.19 * * *$ \\
& $(-10.54)$ & $(-2.11)$ & $(-1.49)$ & $(-2.74)$ & $(-6.66)$ & $(-7.61)$ & $(4.08)$ \\
IO & $-0.14 * * *$ & $-0.38 * * *$ & $-0.27 * * *$ & $-0.19 * * *$ & $-0.14 * * *$ & $-0.10 * * *$ & $-0.06 * * *$ \\
& $(-37.30)$ & $(-22.53)$ & $(-19.07)$ & $(-17.06)$ & $(-16.62)$ & $(-14.52)$ & $(-8.86)$ \\
\hline Adj.R & 0.09 & 0.22 & 0.13 & 0.10 & 0.10 & 0.08 & 0.08 \\
$N$ & 20143 & 2384 & 3006 & 3391 & 3616 & 3524 & 4222 \\
\hline
\end{tabular}

Note: Numbers in parentheses are $t$-statistics of the regression coefficients. ${ }^{* * *}, * *$, and ${ }^{*}$ correspond to statistical significance at the $1 \%, 5 \%$, and $10 \%$ level, respectively.

First, we analyze the regression results of the total sample. The second column of Table 6 shows that regression coefficient of $U E$ is 0.07 with significance at $5 \%$ level, indicating that the institutional investors purchase more shares as earnings surprise of the listed companies becomes larger. That is, earnings surprise encourages the institutional investors to adjust their portfolios. This is consistent with expectations and supports Hypothesis 2. The regression coefficient of $B M$ is 2.88 , meaning that the higher the book-to-market ratio of the company, the more likely institutional investors tend to increase their shareholdings, that is, institutional investors choose companies with undervalued assets. For TRAC, its regression coefficient is 
0.14. It seems that institutional investors inclined to buy more stocks with higher transaction costs, which is contrary to common sense. In fact, TRAC represents the average share price during the window period. On one hand it reflects the transaction cost; on the other hand it also shows the value of the stock. From this perspective, the increase in share price is in line with increase in institutional investors shareholdings. The coefficient of -4.00 for Dpro shows that institutional investors are more likely to reduce shares with large stock dividends. This finding supports the optimal sequence financing theory: Institutional investors believe that large stock dividend conveys information of over-valued share price. The regression coefficient for $U E$ is -0.22 , which reveals that the greater the earnings of the previous period, the more likely institutional investors tend to sell their shares. Since current earning is the best estimate for earnings of the next period, institutional investors are supposed to increase their holdings. Obviously, this is not consistent with our expectations. We believe that the proportion of irrational individual investors in Chinese stock market is relatively high. They tend to be easily influenced by Herding Effect, and over-react to good news with high earnings stocks, therefore, pushing up share prices as a result. While the rational institutional investors take advantage of the irrationality of individual investors to reverse the operation and sell their high earnings stocks. In Table 5, the inverse "U" shape curve characteristics for $\triangle I O$ and $U E$ also prove this point. The coefficient of -0.14 for $I O$ suggests that if institutional investors hold more shares in the previous period, they are more inclined to decrease their shares in the current period, which is shown in Table 5 .

Second, we analyze regression results for the sub-sample. The coefficient for $S U E$ is not stable, and the results of the year 2008, 2010, 2011 and 2012 are negative but not significant, showing that institutional investors do not significantly adjust their portfolio according to earnings surprise. To some extent the result verifies the existence of institutional investors' portfolio adjustment inertia. Further analysis shows that the year which portfolio adjustments exhibit inertia, is when Chinese A-share market experienced a decline. Therefore, we believe that the essence of portfolio adjustments inertia is institutional investors' disposition effect: In years when the stock market is falling, institutional investors still hold plenty of stocks with accounting losses and do not reduce their shares rapidly. In the year of 2007 and 2009, the coefficients for $U E$ are significantly positive and it is these two years when there is a sharp increase in the A-share market. This shows that when the market as a whole is better off, institutional investors actively adjust the asset portfolio according to changes in earnings surprise. The regression coefficients for the control variables are almost consistent with results for the total sample.

Table 6 and its analysis show that if institutional investors express some activeness in portfolio adjustments during a rising stock market, then Hypothesis 2 is well established; instead, if institutional investors do so during a falling market, then Hypothesis 2 will not be established. Institutional investors, to some extent, exhibit portfolio adjustment inertia as they do not significantly adjust their portfolio according to variation of earnings surprise. Basili and Fontini $^{[22]}$, Asano ${ }^{[23]}$ and Illeditsch ${ }^{[8]}$ regarded the ambiguity as necessary premise to form the asset portfolio inertia. Before the regular earnings announcements of listed companies, future accounting earnings are considered as the ambiguity information. Therefore, this paper not 
only provides strong empirical support for the related theory of asset portfolio inertia, but also, for the first time, concludes that the formation of portfolio adjustment inertia is subject to market conditions.

2) Regression results and analysis of Model (6)

In Model (6), we investigate the premise for the existence of mediation effect: The significance of $\beta_{1}$ is the main criterion of telling whether mediation effect exists. Referred to related literature, the choice of the control variables is slightly different from Model (5). As institutional investors show portfolio adjustment inertia in a declining market, we will further divide the total sample into inertia group and non-inertia group. Results are shown in Table 7.

Table 7 Regression results of Model (6)

\begin{tabular}{|c|c|c|c|c|c|c|}
\hline & Total sample & & Inertia group & & Inertia group & \\
\hline$U E$ & $\begin{array}{c}2.9202 * * * \\
(11.89)\end{array}$ & $\begin{array}{c}0.5973 * * * \\
(3.13)\end{array}$ & $\begin{array}{c}5.8448 * * * \\
(14.11)\end{array}$ & $\begin{array}{c}0.3991 * \\
(1.77)\end{array}$ & $\begin{array}{c}1.3797 * * * \\
(4.95)\end{array}$ & $\begin{array}{c}0.6632 * * * \\
(3.12)\end{array}$ \\
\hline$B M$ & & $\begin{array}{c}-0.5637 * * * \\
(-20.73)\end{array}$ & & $\begin{array}{c}-0.9592 * * * \\
(-25.76)\end{array}$ & & $\begin{array}{c}-0.5444 * * * \\
(-14.90)\end{array}$ \\
\hline$T R A C$ & & $\begin{array}{c}0.0074 * * * \\
(15.16)\end{array}$ & & $\begin{array}{c}0.0046 * * * \\
(6.41)\end{array}$ & & $\begin{array}{c}0.0089 * * * \\
(15.28)\end{array}$ \\
\hline Dpro & & $\begin{array}{c}0.1408 * * * \\
(6.79)\end{array}$ & & $\begin{array}{c}0.1279 * * * \\
(3.81)\end{array}$ & & $\begin{array}{c}0.1116 * * * \\
(4.88)\end{array}$ \\
\hline TURV & & $\begin{array}{c}23.8307 * * * \\
(94.67)\end{array}$ & & $\begin{array}{c}24.4116 * * * \\
(64.79)\end{array}$ & & $\begin{array}{c}23.4330 * * * \\
(77.69)\end{array}$ \\
\hline$S I Z E$ & & $\begin{array}{c}-0.2011 * * * \\
(-18.68)\end{array}$ & & $\begin{array}{c}-0.2028 * * * \\
(-12.24)\end{array}$ & & $\begin{array}{c}-0.1260 * * * \\
(-10.04)\end{array}$ \\
\hline FORC & & $\begin{array}{c}-0.1224 * * * \\
(-11.41)\end{array}$ & & $\begin{array}{c}-0.2423 * * * \\
(-14.13)\end{array}$ & & $\begin{array}{l}-0.0144 \\
(-1.18)\end{array}$ \\
\hline$L A G$ & & $\begin{array}{c}-0.0010 * * * \\
(-5.98)\end{array}$ & & $\begin{array}{c}-0.0006 * * \\
(-2.21)\end{array}$ & & $\begin{array}{l}-0.0002 \\
(-1.27)\end{array}$ \\
\hline Industry factor & Control & Control & Control & Control & Control & Control \\
\hline $\operatorname{Adj} . R$ & 0.11 & 0.43 & 0.12 & 0.51 & 0.10 & 0.44 \\
\hline$N$ & 20143 & 20143 & 14368 & 14368 & 5775 & 5775 \\
\hline
\end{tabular}

Note: Numbers in parentheses are $t$-statistics of the regression coefficients. ${ }^{* * *}, * *$, and ${ }^{*}$ correspond to statistical significance at the $1 \%, 5 \%$, and $10 \%$ level, respectively.

Table 7 shows that the coefficients $\beta_{1}$ for $U E$ are positive at $1 \%$ significant level in both the total sample and sub-sample, which satisfies the premise of mediation effect tests ${ }^{[25]}$. After joining the control variable, $\beta_{1}$ is still significant but with a smaller value, and the size of adjusted R2 becomes larger. This shows that the inclusion of control variables reduces the influence of earnings surprise on share price volatility, but improves the fitting degree of the 
model. Except for FORC and $L A G$ from the non-inertia group, the coefficients for other control variables are significant and consistent with expectations.

3) Regression results and analysis of Model (7)

The results of Model (5) support Hypothesis 2, and those of Model (6) prove that the premise for the existence of mediation effect is established. Model (7) is used to test Hypotheses 3 and 4 , and the significance of coefficient $\gamma_{1}$ for $\Delta I O$ is the core variable to tell the existence of mediation effect. The results are shown in Table 8.

Table 8 Regression results of Model (7)

\begin{tabular}{|c|c|c|c|c|c|c|}
\hline & Total sample & & Inertia group & & Inertia group & \\
\hline$\Delta I O$ & $\begin{array}{c}0.0050 * * * \\
(8.81)\end{array}$ & $\begin{array}{c}0.0035 * * * \\
(7.89)\end{array}$ & $\begin{array}{l}0.0021 \\
(0.99)\end{array}$ & $\begin{array}{l}0.0011 \\
(0.86)\end{array}$ & $\begin{array}{c}0.0078 * * * \\
(11.49)\end{array}$ & $\begin{array}{c}0.0054 * * * \\
(10.17)\end{array}$ \\
\hline$U E$ & $\begin{array}{c}2.9411 * * * \\
(12.00)\end{array}$ & $\begin{array}{c}0.5724 * * * \\
(2.99)\end{array}$ & $\begin{array}{c}5.8705 * * * \\
(14.17)\end{array}$ & $\begin{array}{c}0.3677 * \\
(1.86)\end{array}$ & $\begin{array}{c}1.3686 * * * \\
(4.94)\end{array}$ & $\begin{array}{c}0.6213 * * * \\
(2.93)\end{array}$ \\
\hline$B M$ & & $\begin{array}{c}-0.5842 * * * \\
(-21.58)\end{array}$ & & $\begin{array}{c}-0.9629 * * * \\
(-25.83)\end{array}$ & & $\begin{array}{c}-0.5821 * * * \\
(-16.14)\end{array}$ \\
\hline$T R A C$ & & $\begin{array}{c}0.0070 * * * \\
(14.56)\end{array}$ & & $\begin{array}{c}0.0043 * * * \\
(6.08)\end{array}$ & & $\begin{array}{c}0.0085 * * * \\
(15.03)\end{array}$ \\
\hline Dpro & & $\begin{array}{c}0.1588 * * * \\
(7.61)\end{array}$ & & $\begin{array}{c}0.1532 * * * \\
(4.52)\end{array}$ & & $\begin{array}{c}0.1299 * * * \\
(5.67)\end{array}$ \\
\hline$T U R V$ & & $\begin{array}{c}23.9712 * * * \\
(95.49)\end{array}$ & & $\begin{array}{c}24.6698 * * * \\
(65.68)\end{array}$ & & $\begin{array}{c}23.4660 * * * \\
(78.09)\end{array}$ \\
\hline$S I Z E$ & & $\begin{array}{c}-0.1883 * * * \\
(-18.01)\end{array}$ & & $\begin{array}{c}-0.1791 * * * \\
(-11.06)\end{array}$ & & $\begin{array}{c}-0.1235 * * * \\
(-10.17)\end{array}$ \\
\hline FORC & & $\begin{array}{c}-0.1126 * * * \\
(-10.50)\end{array}$ & & $\begin{array}{c}-0.2329 * * * \\
(-13.59)\end{array}$ & & $\begin{array}{l}-0.0026 \\
(-0.21)\end{array}$ \\
\hline$L A G$ & & $\begin{array}{c}-0.0007 * * * \\
(-4.19)\end{array}$ & & $\begin{array}{c}-0.0004 * * * \\
(-1.41)\end{array}$ & & $\begin{array}{l}0.0002 \\
(1.01)\end{array}$ \\
\hline Industry factor & Control & Control & Control & Control & Control & Control \\
\hline Year factor & Control & Control & Non-control & Non-control & Non-control & Non-control \\
\hline Adj.R & 0.11 & 0.42 & 0.12 & 0.50 & 0.11 & 0.43 \\
\hline$N$ & 20143 & 20143 & 14368 & 14368 & 14368 & 14368 \\
\hline
\end{tabular}

Note: Numbers in parentheses are $t$-statistics of the regression coefficients. ${ }^{* * *}, * *$, and ${ }^{*}$ correspond to statistical significance at the $1 \%, 5 \%$, and $10 \%$ level, respectively.

From Table 8, we can see that adjusted $R^{2}$ is between 0.11 and 0.50 , indicating the strong explanatory power of variables. Comparing the inclusion of control variables to the exclusion of them, we find that the signs of correlation coefficients are the same, but the model fitting degree is improved significantly, suggesting that the selection of control variable is reasonable.

First, we analyze the regression results for total samples. The coefficient $\gamma_{1}$ for $\Delta I O$ is 0.0035 
with significance at $1 \%$ level, showing that $\triangle I O$ has a remarkable effect on $V O L$, after controlling for other factors. Apparently, the influence of earnings surprise on the stock price volatility can be exerted by institutional investors' portfolio adjustment. This is basically accordance with the conclusion of Yue and Zhou ${ }^{[12]}$ that fluctuation in proportion of institutional shareholdings is the most important source for volatility of the Shanghai Composite Index. Further analysis of Table 4 shows that the coefficient for $\Delta I O$ is the minimum when that for $U E$ is the maximum, while the corresponding coefficient for $V O L$ is at its maximum level. This illustrates that $V O L$ is not completely dominated by institutional investors. In the sample period, individual investors still remain important to have a significant impact on share price volatility. Therefore, partial mediation effect is imposed by the trading of individual investors, which can be seen from the coefficients of $U E$. The coefficient of $\gamma_{2}$ is 0.5724 , which is positively significant and greater than $\gamma_{1}$.

Second, we compare the regression results of inertia group to those of non-inertia group and conclude that hypothesis 3 is well established. The regression coefficient of $\Delta I O$ is insignificant in inertia group, but is positively significant in non-inertia group. This difference shows that: For inertia group, institutional investors inactively adjust their portfolio according to earnings surprise of listed companies, therefore, no remarkable volatility is found in share prices. For the non-inertia group, institutional investors actively adjust portfolio to significantly enhance share prices volatility. Hence, with respect to earnings surprise of listed companies, the stronger inertia the portfolio adjustment by institutional investors, the smaller fluctuations of related stock prices, and vice versa. Thus, Hypothesis 3 is established. Combined with the results of Tables 6, 7 and 8, we can see that, the characteristics of institutional investors' portfolio adjustments (inertia or activeness) exert significant effects on related stock price volatility, based on earnings surprise of listed companies. Therefore, the existence of the mediation effect is strongly proved and hypothesis 4 is established.

Finally, we examine the regression results for the control variables. The coefficients for $T R A C, T U R V$ and Dpro are positively significant, suggesting that the higher the transaction costs, the stronger the investor sentiments, the more likely the listed company engages in large stock dividends, the greater is the share price volatility. The coefficients for BM, SIZE, FORC fand $L A G$ are negatively significant, indicating that the higher the book-to-market ratio, the greater the size of company assets, the more easier is to stabilize the stock prices. The listed companies that issue pre-announcement earnings present relatively low share price volatility, it shows that pre-announcement earnings releases part of the profit information. The more delayed the date for actual earnings announcement, the less the impacts of announcement on stock price volatility. Since investors have more time to collect and process information before earnings announcements, they can predict earnings more reasonably and respond in advance. The similar results of whether to control for the industry factors indicate that the difference between industries has no influence on stock price volatility. Moreover, share price volatility has eliminated the systematic effect of the market, therefore, the results are barely affected by whether to control for the annual factors, such as the macroeconomics. 


\subsection{Robustness Test}

First, this paper defines earnings surprise (UE) as dummy variables (Due) in two ways: One is to categorize by the signs, if UE is positive, then we assume a value of 1 for Due1; if UE is negative, then we assume a value of 0 for Due1. The other is to divide UE into ten equal parts in an ascending order and Due2 takes the values from 1 to 10 respectively. Second, we replace UE in Models (5), (6) and Model (7) with Due1 and Due2 respectively to run the tests. The same test results are obtained as the previous tests, thus, our conclusion supports the robustness of above empirical results (Limited to space, robustness test results are not reported here; if necessary, please contact the author).

\section{Conclusions}

From the perspective of mediation effect, this paper uses the regularly published data from Chinese A-share market over the period 2007-2012 to examine the internal logic relationship among the earnings surprise of listed companies, portfolio adjustments of institutional investors, and the share prices volatility. The conclusions are summarized as follows: 1) Earnings surprise is often observed in the A-share market, which results from both macroeconomics, and microeconomic factors. 2) For earnings surprise, when they are classified by the positive or negative signs, there is slightly difference on portfolio adjustments by institutional investors; but when classified by the magnitudes, their portfolio adjustments exhibit characteristics of the inverse "U" shape. 3) Institutional investors' portfolio adjustments impose a significant mediation effect on the relationship between earnings surprise and share prices volatility: After controlling for other factors, when there is a rising stock market, the greater the earnings surprise, the higher the activeness, and the larger the magnitude for institutional investors to adjust their portfolios, leading to amplify the mediation effect and enhance stock price volatility; when there is a falling stock market, institutional investors inactively adjust their portfolio positions regarding the scale of earnings surprise, and to some extent, present portfolio adjustment inertia, and result in depressing the mediation effect and reducing the stock price volatility. Apparently, this is different from the single conclusion of "intensified" or "stability" theory in other literature. 4) The formation of portfolio adjustment inertia is affected by the market environment, and more prone to exist in a declining market.

The conclusions of this paper have important implications for regulators. First, in such a "emerging plus transition" Chinese capital market, the information quality plays an influential role in the formation of earnings surprise and improvement of asset pricing efficiency. Thus, from the perspective of information supply, information demand and information transmission, it is fundamental to strengthen the supervision of information disclosure of listed companies, and to reduce the incomplete information and so on. It also puts forward the urgent request for the basic system supply of China's capital market. Second, although institutional investors present portfolio adjustment inertia during a declining stock market to contribute reduction in stock price volatility, they actively adjust their portfolios during a rising stock market to accelerate share price volatility. The behavior of "chase-up and kill-down" is not completely consistent with the initial purpose of vigorously developing institutional investors to stabilize the market, and is to the blame for obtaining many preferential policies (such as rights of issue 
priority, etc.). Yue and Zhou ${ }^{[12]}$ also believe that the policy to stabilize the securities market is unrealistic through the development of the supernormal institutional investors. Therefore, preferential policies inclined to institutional investors should be eliminated, and all investors should play on an equal field to improve the degree of market competition for institutional investors. Third, the violation behaviors conducted by institutional investors such as insider trading, market manipulation, the indemnification etc., are not only often observed but also renovated ceaselessly, invisibly, and involved more striking amounts of money. This ubiquitous behavior in the A-share market is of the main factor of share price volatility for individual stocks, and is also widely criticized by the public. Hence, we should not only strengthen market supervision, crack down on illegal behavior by the institutional investors, but also reduce administrative intervention, advocate the spirit of the rule of law, and promote institutional change of the capital market with the market principle, so as to promote the sustainable and healthy development of Chinese capital market.

The limitation of this paper is that it uses quarterly changes in the proportion of individual stocks held by institutional investors to replace changes in their asset portfolios. If the high-frequency data on assets portfolio changes in each security owned by specific institutional shareholders are obtained, then we will make empirical study more ideal. Moreover, the conclusion of this paper is based on only 23 quarterly observations in six years, it is necessary to test the hypothesis over the longer time period. This will be the next research direction in the paper.

\section{References}

[1] Berkman H, McKenzie M D. Earnings announcements: Good news for institutional investors and short sellers. Financial Review, 2012, 47(1): 91-113.

[2] Braun P A, Nelson D B, Sunier A M. Good news, bad news, volatility, and betas. The Journal of Finance, 1995, 50(5): 1575-1603.

[3] Epstein L G, Schneider M. Ambiguity, information quality, and asset pricing. The Journal of Finance, 2008, 63(1): 197-228.

[4] Williams C D. Asymmetric responses to good and bad news: An empirical case for ambiguity. Working Paper, 2009.

[5] Gerard X. Information uncertainty and the post-earnings announcement drift in Europe. Financial Analysts Journal, 2012, 68(2): 51-69.

[6] Yu L S, Wang Y Y. The relationship between uncertainty about information and post earnings announcement drift: Evidence from the experiences of China's listed companies. Management World, 2006(3): $40-52$.

[7] Shi R S, Chen G M. Can individual investors interpret public information? A research on the information demand around the announcement of earnings. Securities Market Herald, 2012(9): 16-22.

[8] Illeditsch P K. Ambiguous information, portfolio inertia, and excess volatility. The Journal of Finance, 2011, 66(6): 2213-2247.

[9] Dennis P J, Deon S. Who blinks in volatile markets, individuals or institutions. The Journal of Finance, 2002, 57(5): 1923-1949.

[10] Yan X S, Zhang Z. Institutional investors and equity returns: Are short-term institutions better informed. Review of financial Studies, 2009, 22(2): 893-924.

[11] Dasgupta A, Prat A, Verardo M. The price impact of institutional herding. Review of Financial Study, 2011, 24(3): 892-925.

[12] Yue Y J, Zhou K F. Influence of institutional investor on the volatility of stock market: Based on research into the Topview Data. China Industrial Economics, 2009(3): 140-148. 
[13] Chen G J, Zhang Y J, Liu C. Do institutional investors aggravate the instability of stock markets: Evidence from Shanghai A-Share market. Journal of Financial Research, 2010(11): 45-59.

[14] Liu Y J, Hu Y M. Institutional investors, fair value and market volatility: Empirical evidence from the panel data of A-share stock market in China. Journal of Finance and Economics, 2010(2): 54-64.

[15] Faugere C, Shawky H A. Volatility and institutional investor holdings in a declining market: A study of NASDAQ during the year 2000. Journal of Applied Finance, 2003, 13(2): 32-42.

[16] Qi B, Huang M, Chen Z S. Institutional investors and the volatility of stock market. Journal of Financial Research, 2006(9): 54-64.

[17] Ameriks J, Zeldes S. How do household portfolio shares vary with age. Working Paper, 2004.

[18] Bilias Y, Georgarakos D, Haliassos M. Portfolio inertia and stock market fluctuations. Journal of Money, Credit and Banking, 2010, 42(4): 715-742.

[19] Barber B M, Odean T. Trading is hazardous to your wealth: The common stock investment performance of individual investors. Journal of Finance, 2000, 55(2): 773-806.

[20] Asano T. Portfolio inertia under ambiguity. Mathematical Social Sciences, 2006, 52(3): 223-232.

[21] Lev B, Nissim D. The persistence of the accruals anomaly. Contemporary Accounting Research, 2006, 23(1): 193-226.

[22] Basili M, Fontini F. Ambiguity and portfolio inertia. International Journal of Theoretical and Applied Finance, 2002, 5(8): 785-795.

[23] Asano T. Portfolio inertia and epsilon-contaminations. Theory and Decision, 2010, 68(3): 341-365.

[24] Bernard V, Thomas J. Evidence that stock prices do not fully reflect the implications of current earnings for future earnings. Journal of Accounting and Economics, 1990(13): 305-340.

[25] Wen Z L, Zhang L. Testing and application of the mediating effects. Acta Psychological Sinica, 2004(5): $614-620$

[26] Collins D W, Gong G J, Hribar P. Investor sophistication and the mispricing of accruals. Review of Accounting Studies, 2003, 8(2-3): 251-276. 